\title{
The distribution of nutrient intake within families
}

\author{
BY MICHAEL NELSON* \\ $M R C$ Environmental Epidemiology Unit, Southampton General Hospital, \\ Southampton SO9 $4 \mathrm{XY}$
}

(Received 5 July 1985 - Accepted 16 October 1985)

1. During 1978 and 1979 , the 343 members of seventy-nine families representative of households with two adults and two or three children living in Cambridge, England, completed 7-d records of food consumption using the semi-weighed technique. Nutrient intakes were calculated using food composition tables.

2. Amongst males, the average intakes of energy and most nutrients were highest in men and boys aged 11-17 years, and lowest in boys under 5 years. Amongst females, intakes were highest in girls aged 11-17 years, and lowest in those under 5 years. At each age, intakes in males were generally higher than those in females.

3. Nutrient distribution within families was described using the ratio, intake of each subject: intake of the male head of the household. The problems inherent in using this ratio are discussed.

4. The distribution of nutrient intakes within the families was not in accordance with the recommended daily amounts (RDA). Men and young boys received more than their fair share of the family diet, while women and girls aged 5-17 years received less.

5 . Estimates of dietary adequacy based on the averages of family consumption and requirements (RDA) concealed up to twofold variations in the adequacy of diet of different age-sex-groups.

6. The interpretation of dietary adequacy in household food surveys should take into account the distribution of nutrient intakes within the household, as the distribution may be substantially different from that predicted by the RDA.

Studies of family food consumption such as the National Food Survey (NFS) (Ministry of Agriculture, Fisheries and Food, 1984) give no indication of how nutrients are distributed within families. Yet it is known that men often receive more than their 'fair share' of food, and estimates of the average adequacy of family diets have been shown to conceal systematic variations in the adequacy of the diets of particular subgroups (husbands, wives, teenage children, etc.) (den Hartog, 1972; Ferro-Luzzi et al. 1981). Knowledge of nutrient distribution within families is therefore vital to the interpretation of family-diet studies.

Earlier this century, the distribution of energy intakes within families was described in terms of man-values (Medical Research Committee, 1917; Medical Research Council, 1924; Paton \& Findley, 1926; Cathcart \& Murray, $1931 a$; British Medical Association, 1933). A man-value was defined as the ratio, intake in a particular age-sex-group: intake in adult males (United States Department of Agriculture, 1900). However, there were a number of weaknesses in describing the distribution of nutrient intakes in this way, the most important of which was that man-values were, by definition, dependent on the man's intake. It was recognized that the intake of a miner's wife relative to her husband was proportionately much less than that of a clerk's wife relative to her husband (Cathcart \& Murray, 1931 b). Researchers did not have the necessary information to standardize man-values for men's occupation, level of activity or age, and this led to the publication of a bewildering variety of values and age-groupings which revealed the uncertainty about their proper derivation.

More recent studies of nutrient distribution within families have simply reported the measured intake according to age and sex (Hitchcock \& Gracey, 1978) or have expressed the relative adequacy of the diets of family subgroups in terms of recommended dietary allowances (Valenzuela et al. 1979; Florencio \& Aligaen, 1980; Ferro-Luzzi et al. 1981).

The aim of the present paper is (a) to describe the nutrient intake and distribution in

\footnotetext{
* Present address: Department of Nutrition, King's College London (KQC), Campden Hill Road, London W8 7AH.
} 
Table 1. Number and mean age of individuals in eight age-sex-groups in seventy-nine Cambridge families

\begin{tabular}{|c|c|c|c|c|c|c|c|c|}
\hline \multirow{2}{*}{$\begin{array}{l}\text { Age-group (years)... } \\
\text { Sex... }\end{array}$} & \multicolumn{2}{|c|}{18 and over } & \multicolumn{2}{|c|}{$11-17$} & \multicolumn{2}{|c|}{$5-10$} & \multicolumn{2}{|c|}{ Under 5} \\
\hline & $\hat{o}$ & q & 3 & q & $\hat{\sigma}$ & q & $\delta$ & $q$ \\
\hline No. & 79 & 79 & 27 & 26 & 34 & 38 & 36 & 24 \\
\hline Mean age (years) & $35 \cdot 5$ & $32 \cdot 9$ & $14 \cdot 0$ & $13 \cdot 1$ & $7 \cdot 7$ & $7 \cdot 6$ & $2 \cdot 0$ & $2 \cdot 6$ \\
\hline
\end{tabular}

seventy-nine Cambridge families all of whose 343 members completed 7-d records of food consumption, (b) to examine patterns of consumption within these families, and (c) to compare the estimated adequacy of the average family diet with the adequacy of the diets of groups of like individuals within the families.

\section{METHODS}

\section{Sample selection}

Two groups of volunteer families were recruited through local schools and health visitors in 1978. The first group consisted of families from social classes I, II and III manual and non-manual, while the second consisted of large families (up to five children) on low incomes from social classes III manual, IV and V (Office of Population Censuses and Surveys, 1971). A final study in 1979 was based on a random sample of 722 households selected from the electoral register in Cambridge. Following a letter of introduction, this sample was screened for households with two adults and two or three children. The range of household composition was restricted in order to provide sufficient information on households of a defined composition. Further details of sample selection and cooperation are given in a. previous paper (Nelson et al. 1985).

For the study of nutrient distributions within families, it was necessary that all individuals maintained their regular eating habits throughout the survey, and that no-one was ill. Of the eighty-two families originally selected, three were excluded because the man was ill or on a short-term reducing diet. In three other families the women were on long-standing reducing diets, and these families were retained for the present calculations.

Each family consisted of one man and one woman aged between 18 and 57 years, and two or three children aged between 0 and 17 years. None of the infants was being breast-fed. Because of the small number of children at each year of age, it was necessary for purposes of analysis to group the children into three categories: preschool ( $0-4$ years), young school-age (5-10 years), and adolescent (11-17 years). The sample composition is given in Table 1 .

\section{Food consumption records}

Families kept records of each individual's food consumption over seven consecutive days using the semi-weighed method (Nelson \& Nettleton, 1980), in which total family intakes were weighed, while the intake of each individual was based primarily on household measures, which were quantified for each family. The housewife was also asked to record recipes of home-cooked dishes and the weights of prepared vegetables served to the entire family. The consumption of all food eaten at home and away from home was recorded, including the consumption of alcoholic beverages, soft drinks, and sweets.

Nutrient intakes were calculated primarily using the computer version of McCance and Widdowson's food composition tables (Paul \& Southgate, 1978), supplemented with 
calculations from recipes of the nutrient content of an extra eighty-five dishes (Wiles $e t$ al. 1980). Analytical values were obtained for a limited number of other foods not listed in the food tables.

\section{Nutrient distribution}

The distribution of nutrient intakes within families was described using two measurements: (1) man-values: the man-value of a particular age-sex-group for a given nutrient was defined as the average intake in that group divided by the average intake in adult males; (2) family-values: the estimated nutrient intake of each family member was divided by the intake of the male head of household. The family-value was defined as the average of these values in a particular age-sex-group.

By definition, the man-value and family-value of adult males is equal to unity.

\section{Dietary adequacy}

The adequacy of each individual's nutrient intake $\left(\% \mathbf{R D A}_{\mathrm{i}}\right)$ was calculated by dividing the estimated nutrient intake, based on the 7-d semi-weighed record, by the recommended daily amount (RDA) (Department of Health and Social Security, 1979) appropriate for that person's age and sex, and mutiplying by 100 . The average adequacy of diet in each age-sex group $\left(\% \mathrm{RDA}_{\mathrm{g}}\right)$ was equal to the mean of the values for $\% \mathrm{RDA}_{\mathrm{i}}$ in that group. The adequacy of each household's diet was equal to the sum of the measured intakes of the family members divided by the sum of their RDA multiplied by 100 . The average adequacy of the household diets, $\% \mathrm{RDA}_{\mathrm{h}}$, was equal to the sum of the values for the dietary adequacy of each household divided by the total number of households.

This study was approved by the Ethical Committee of the MRC Dunn Nutrition Unit, Cambridge.

\section{RESULTS}

Nutrient intakes by age and sex

The average daily intakes of energy and eleven nutrients in eight age-sex-groups are given in Table 2. Amongst males, intakes were highest in men for all nutrients except thiamin and dietary fibre, for which intakes were as great or greater in boys aged 11-17 years. Boys under 5 years had the lowest intakes. Amongst females, girls aged 11-17 years had the highest nutrient intakes except for retinol equivalents, riboflavin and ascorbic acid, for which intakes were higher amongst women. Girls under 5 years had the lowest intakes. Within each age-group, intakes were generally higher in the males than in the females, but there were exceptions, for instance retinol equivalents and ascorbic acid in those aged 11-17 years and under 5 years.

\section{Man-values and family-values}

The average man-values and family-values for energy intakes in eight age-sex-groups in the seventy-nine families were calculated as described above and the results are shown in Table 3. Family-values were on average between 1 and 6 percentage points larger than the man-values, that is, there was less divergence in intakes within families than in the population as a whole. This suggests that to some extent families contained all big eaters or all small eaters, and this can readily be shown.

Subjects within each age-sex-group were classified into thirds of the distribution of energy intake. There was a tendency for members of the same family to occupy the same third in their respective distributions of intake.

For example, of the twenty-six women in the top third of the distribution, eleven $(42 \%)$ 
Table 2. Mean measured daily intakes of energy and eleven nutrients in 343 individuals in seventy-nine Cambridge families, according to age and sex

(Mean values with their standard errors)

\begin{tabular}{|c|c|c|c|c|c|c|c|c|c|}
\hline \multicolumn{2}{|l|}{ Age-group (years)... } & \multicolumn{2}{|c|}{18 and over } & \multicolumn{2}{|c|}{$11-17$} & \multicolumn{2}{|c|}{$5-10$} & \multicolumn{2}{|c|}{ Under 5} \\
\hline Nutrient & $\begin{array}{l}\text { Sex... } \\
n \ldots\end{array}$ & $\begin{array}{c}0 \\
79\end{array}$ & $\begin{array}{c}q \\
79\end{array}$ & $\begin{array}{c}0 \\
27\end{array}$ & $\stackrel{9}{+}$ & $\begin{array}{c}0 \\
34\end{array}$ & $\begin{array}{c}q \\
38\end{array}$ & $\begin{array}{l}0 \\
36\end{array}$ & $\begin{array}{c}q \\
24\end{array}$ \\
\hline \multirow[t]{2}{*}{ Energy (MJ) } & Mean & 11.87 & $8 \cdot 06$ & $10 \cdot 20$ & 8.93 & $8 \cdot 27$ & $7 \cdot 06$ & $5 \cdot 76$ & $5 \cdot 56$ \\
\hline & SE & $0 \cdot 34$ & 0.21 & 0.33 & 0.30 & $0 \cdot 29$ & 0.20 & 0.28 & 0.20 \\
\hline \multirow[t]{2}{*}{ Protein (g) } & Mean & $89 \cdot 4$ & $63 \cdot 4$ & $70 \cdot 2$ & $64 \cdot 0$ & $59 \cdot 2$ & $48 \cdot 9$ & $44 \cdot 4$ & $38 \cdot 5$ \\
\hline & SE & $2 \cdot 4$ & $1 \cdot 6$ & $2 \cdot 4$ & $2 \cdot 6$ & $2 \cdot 8$ & $1 \cdot 2$ & $2 \cdot 0$ & $2 \cdot 5$ \\
\hline \multirow[t]{2}{*}{ Fat $(\mathrm{g})$} & Mean & $123 \cdot 7$ & $87 \cdot 5$ & $104 \cdot 3$ & $95 \cdot 4$ & $84 \cdot 4$ & $71 \cdot 1$ & $60 \cdot 9$ & $56 \cdot 0$ \\
\hline & $\mathrm{SE}$ & $3 \cdot 8$ & $2 \cdot 5$ & $3 \cdot 8$ & $4 \cdot 0$ & $3 \cdot 8$ & $2 \cdot 2$ & $2 \cdot 8$ & $2 \cdot 0$ \\
\hline \multirow[t]{2}{*}{ Carbohydrate (g) } & Mean & $330 \cdot 4$ & 223.7 & 313.9 & $267 \cdot 1$ & $256 \cdot 4$ & $222 \cdot 8$ & $171 \cdot 7$ & $177 \cdot 5$ \\
\hline & SE & $9 \cdot 7$ & $7 \cdot 7$ & $11 \cdot 3$ & 8.9 & $9 \cdot 2$ & $7 \cdot 6$ & $10 \cdot 0$ & $7 \cdot 2$ \\
\hline \multirow[t]{2}{*}{ Calcium (mg) } & Mean & 1130 & 864 & 944 & 879 & 907 & 762 & 779 & 646 \\
\hline & $\mathrm{SE}$ & 40 & 33 & 52 & 50 & 58 & 29 & 42 & 38 \\
\hline \multirow[t]{2}{*}{ Iron (mg) } & Mean & 13.9 & $10 \cdot 0$ & $11 \cdot 8$ & $10 \cdot 5$ & $9 \cdot 4$ & $7 \cdot 6$ & $6 \cdot 2$ & $7 \cdot 1$ \\
\hline & $\mathrm{SE}$ & 0.4 & 0.3 & 0.6 & 0.4 & 0.4 & $0 \cdot 3$ & $0 \cdot 3$ & 0.8 \\
\hline \multirow{2}{*}{$\begin{array}{l}\text { Retinol equivalents } \\
(\mu \mathrm{g})\end{array}$} & Mean & 2102 & 1530 & 1026 & 1236 & 975 & 905 & 639 & 644 \\
\hline & SE & 170 & 100 & 93 & 160 & 51 & 69 & 53 & 50 \\
\hline \multirow[t]{2}{*}{ Thiamin (mg) } & Mean & 1.32 & 0.97 & $1 \cdot 42$ & $1 \cdot 13$ & $1 \cdot 21$ & $0 \cdot 94$ & 0.80 & 0.76 \\
\hline & SE & 0.04 & 0.03 & $0 \cdot 10$ & 0.04 & 0.05 & 0.04 & 0.04 & 0.06 \\
\hline \multirow[t]{2}{*}{ Riboflavin (mg) } & Mean & $2 \cdot 20$ & 1.67 & 1.96 & $1 \cdot 56$ & 1.90 & 1.46 & $1 \cdot 51$ & $1 \cdot 26$ \\
\hline & SE & 0.08 & 0.07 & $0 \cdot 12$ & $0 \cdot 10$ & $0 \cdot 11$ & 0.06 & 0.08 & 0.09 \\
\hline \multirow{2}{*}{$\begin{array}{l}\text { Nicotinic acid } \\
\text { equivalents (mg) }\end{array}$} & Mean & 38.7 & $26 \cdot 5$ & $31 \cdot 7$ & $27 \cdot 4$ & $26 \cdot 6$ & $21 \cdot 5$ & $17 \cdot 7$ & $15 \cdot 8$ \\
\hline & $\mathrm{SE}$ & 3.0 & $2 \cdot 1$ & $4 \cdot 4$ & $3 \cdot 7$ & $3 \cdot 2$ & $2 \cdot 5$ & $2 \cdot 0$ & $2 \cdot 0$ \\
\hline \multirow{2}{*}{$\begin{array}{l}\text { Ascorbic acid } \\
\text { (mg) }\end{array}$} & Mean & $55 \cdot 6$ & $52 \cdot 2$ & $46 \cdot 7$ & $49 \cdot 5$ & $37 \cdot 6$ & $32 \cdot 0$ & $28 \cdot 1$ & $34 \cdot 0$ \\
\hline & SE & 2.4 & $4 \cdot 4$ & $5 \cdot 4$ & $4 \cdot 7$ & $3 \cdot 4$ & $2 \cdot 4$ & $3 \cdot 2$ & $5 \cdot 4$ \\
\hline \multirow[t]{2}{*}{ Dietary fibre (g) } & Mean & $17 \cdot 7$ & $13 \cdot 2$ & $17 \cdot 7$ & $16 \cdot 3$ & $14 \cdot 8$ & $12 \cdot 2$ & $8 \cdot 1$ & $8 \cdot 8$ \\
\hline & SE & 0.7 & 0.5 & $1 \cdot 0$ & 0.9 & $0 \cdot 8$ & 0.5 & 0.7 & $1 \cdot 0$ \\
\hline
\end{tabular}

Table 3. Man-values and family-values for energy intakes in eight age-sex-groups in seventy-nine Cambridge families

\begin{tabular}{lccccc}
\hline \hline Age-group (years) ... & & 18 and over & $11-17$ & $5-10$ & Under 5 \\
\hline Males $(n)$ & & 79 & 27 & 34 & 36 \\
Man-values & Mean & 1.00 & 0.86 & 0.70 & 0.48 \\
Family-values & SE & 0 & 0.91 & 0.73 & 0.50 \\
Females $(n)$ & & 79 & 0.04 & 0.03 & 0.03 \\
Man-values & & 0.68 & 0.75 & 0.60 & 0.47 \\
Family-values & Mean & 0.70 & 0.81 & 0.61 & 0.48 \\
& SE & 0.02 & 0.04 & 0.03 & 0.02 \\
\hline
\end{tabular}

Man-value, intake in a particular age-sex-group $\div$ intake in adult males.

Family-value, estimated nutrient intake of each family member $\div$ intake of the male head of the household.

were in families where the men were in the top third of their distribution. Only three $(12 \%)$ of the women in the top third were in families where the men were in the bottom third. A similar concordance was seen for women and men in the bottom thirds of their respective energy distributions, and for children and men in the top and bottom thirds. The observed association of subjects in the extreme thirds within families was highly significant $\left(\chi^{2} 21 \cdot 019\right.$, $P<0.001)$. 
Table 4. Average family-values for energy in eight age-sex-groups, calculated according to the position of the male head of household in the top, middle or bottom third of energy intakes for men in seventy-nine Cambridge families

(Mean values with their standard errors)

\begin{tabular}{|c|c|c|c|c|c|c|c|c|c|c|c|}
\hline \multicolumn{3}{|c|}{$\begin{array}{l}\text { Men's energy intakes } \\
\text { (MJ/person per d) }\end{array}$} & \multirow{2}{*}{$\begin{array}{l}\begin{array}{l}\text { Age-group } \\
\text { (years).. }\end{array} \\
\text { Sex... }\end{array}$} & \multicolumn{2}{|c|}{18 and over } & \multicolumn{2}{|c|}{$11-17$} & \multicolumn{2}{|c|}{$5-10$} & \multicolumn{2}{|c|}{ Under 5} \\
\hline $\begin{array}{l}\text { Third of } \\
\text { intake }\end{array}$ & Mean & SE & & $a$ & $q$ & $\hat{\sigma}$ & q & $\delta$ & $q$ & $\delta$ & $q$ \\
\hline \multirow[t]{2}{*}{ Top } & $14 \cdot 95$ & 0.47 & Mean & $1 \cdot 00$ & 0.58 & 0.75 & 0.68 & 0.59 & 0.47 & 0.41 & $0 \cdot 41$ \\
\hline & & & SE & 0 & 0.03 & 0.05 & 0.06 & 0.03 & 0.02 & 0.03 & 0.02 \\
\hline \multirow[t]{2}{*}{ Middle } & 11.46 & 0.12 & Mean & 1.00 & 0.72 & 0.89 & 0.75 & 0.74 & 0.62 & $0 \cdot 51$ & 0.46 \\
\hline & & & SE & 0 & 0.03 & 0.05 & $0 \cdot 04$ & 0.04 & 0.03 & 0.05 & 0.03 \\
\hline \multirow[t]{2}{*}{ Bottom } & $9 \cdot 22$ & $0 \cdot 18$ & Mean & 1.00 & 0.81 & 1.04 & 0.95 & 0.84 & 0.79 & 0.60 & 0.57 \\
\hline & & & SE & 0 & 0.04 & 0.08 & 0.05 & $0 \cdot 04$ & 0.05 & 0.04 & 0.03 \\
\hline \multicolumn{12}{|c|}{ No. of subjects: } \\
\hline Top & & & - & 26 & 26 & 8 & 7 & 11 & 13 & 15 & 8 \\
\hline Middle & & & - & 27 & 27 & 8 & 9 & 10 & 16 & 10 & 8 \\
\hline Bottom & & & - & 26 & 26 & 11 & 10 & 13 & 9 & 11 & 8 \\
\hline
\end{tabular}

Family-value, estimated nutrient intake of each family member $\div$ intake of the male head of the household.

The differences between man-values and family-values were small compared with the differences in family-values between households in which the men were in different thirds of the distribution of energy intake. Table 4 shows the association between family-values for energy and the rank of men's intakes. In every age- and sex-group, the family-values were lowest where men were in the top third of energy intake and highest where men were in the bottom third. In the age- and sex-groups for children, subjects were grouped according to the position of the male head of the household, hence the unequal numbers in the 'thirds' in these groups.

\section{Family-values for different nutrients}

The average family-values for energy and thirteen nutrients in eight age-sex-groups are given in Table 5. Values for older children aged 11-17 years were generally higher than those for women and younger children. Within each group, males had higher values than females except for retinol, carotene, ascorbic acid and dietary fibre. The family-values for protein were lower than for energy for all groups except women, and males under 5 years; those for iron were less than for energy for children aged 11-17 years old and girls aged 5-10 years. Because of the difficulties involved in measuring individual intakes of retinol and carotene accurately, the family-values for these nutrients may not be very reliable.

\section{Dietary adequacy}

The values for estimated adequacy of diet in each age-sex-group $\left(\% \mathrm{RDA}_{\mathrm{g}}\right)$ and in all households $\left(\% \mathrm{RDA}_{\mathrm{h}}\right)$ are shown in Fig. 1. Overall, the intakes of men, boys aged $0-10$ years, and girls under 5 years were more adequate than intakes in the other groups. The adequacy of intake of males in each age-group was usually greater than that of females.

Although $\% \mathbf{R D A}_{h}$ was very nearly equal to the average adequacy of diet in all subjects, it did not reflect the range of estimated dietary adequacy in different age-sex-groups. For example, $\% \mathrm{RDA}_{\mathrm{h}}$ for energy was 98 . However, the adequacy of energy intakes in men (108) and boys under 5 years (106) was significantly greater than $\% \mathrm{RDA}_{\mathrm{h}}$, and in women (89), boys aged $11-17$ years $(90)$ and girls aged 5-10 years $(90)$ was significantly less (two-tailed 


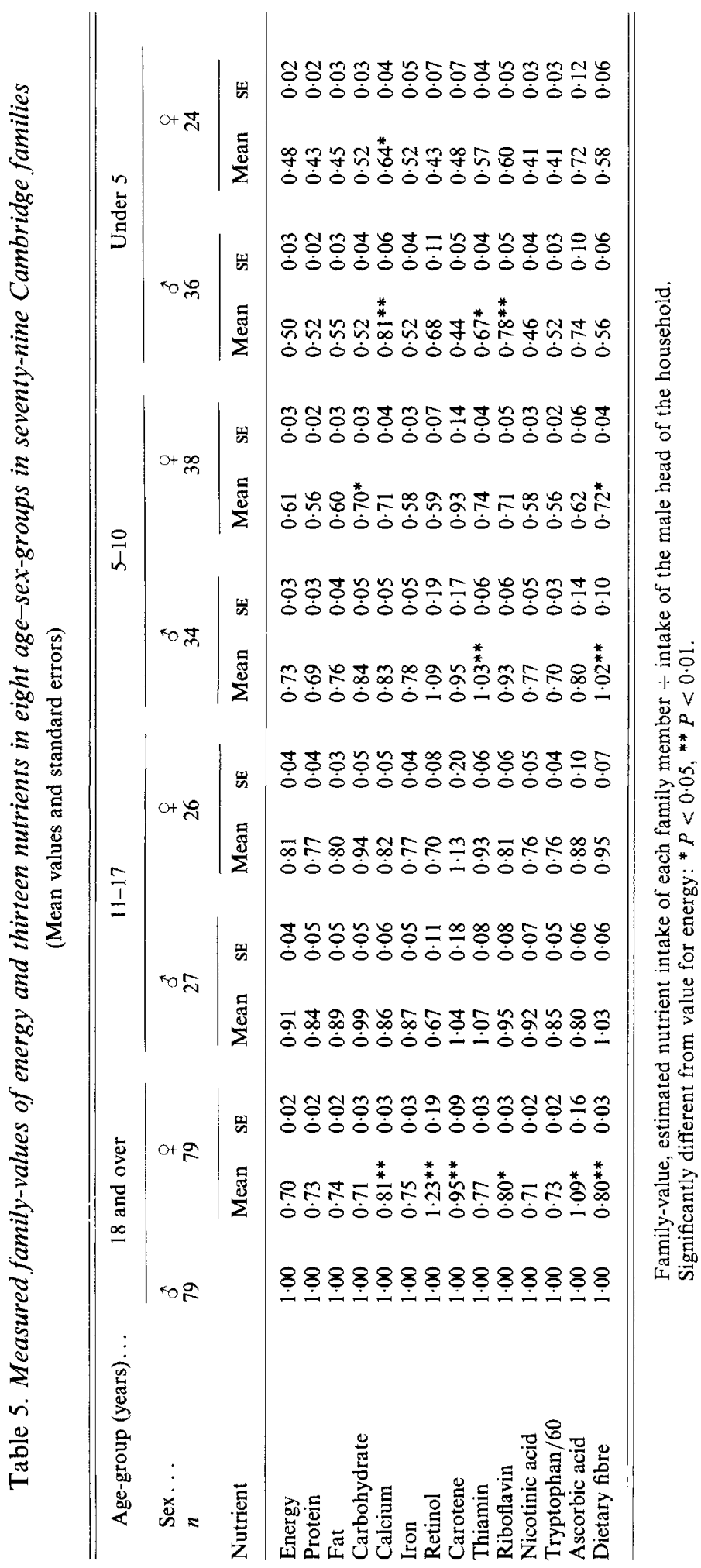



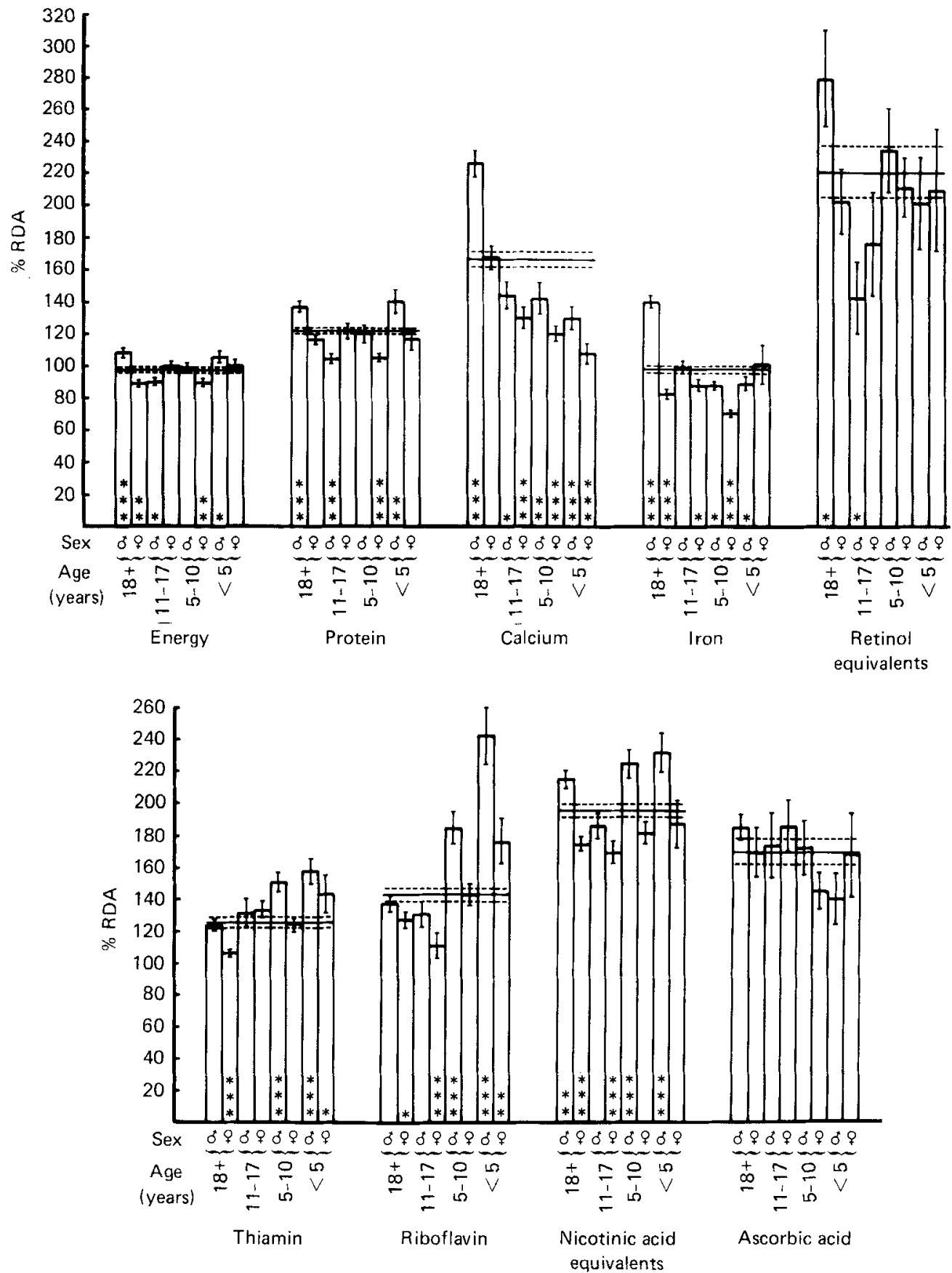

Fig. 1. Estimates of the average adequacy of intakes of nine nutrients in seventy-nine Cambridge families $\left(\% \mathrm{RDA}_{\mathrm{h}}\right)$ and in 343 family members classified in eight age-sex-groups $\left(\% \mathrm{RDA}_{\mathrm{g}}\right)$. Values are means with $1.0 \mathrm{SE}$ of $\% \mathrm{RDA}_{\mathrm{g}}$ represented by vertical bars. (-), \% $\mathrm{RDA}_{\mathrm{h}} ;(---), 1.0 \mathrm{SE}$ of $\% \mathrm{RDA}_{\mathrm{h}}$. Significance of difference between $\% \mathrm{RDA}_{\mathrm{h}}$ and $\% \mathrm{RDA}_{\mathrm{g}}$ (two-tailed unpaired $t$ test): $* P<0 \cdot 05$, ${ }^{* *} P<0.01, * * * P<0.001$. 
unpaired $t$ test). The adequacy of Fe intakes in the households was also 98 , but the variation in the subgroups was much greater than that for energy, ranging from 71 in females aged 5-10 years to 140 in men. The $\% \mathrm{RDA}_{\mathrm{h}}$ concealed an almost twofold difference in dietary adequacy within households. A twofold difference in the adequacy of the diets in the subgroups was also observed for calcium, retinol equivalents and riboflavin.

\section{DISCUSSION}

This is the second report to describe the pattern of nutrient intake as measured within British families. The first report (Cathcart \& Murray, 1931 $a$ ) was based on only five families and used methods of dietary assessment which were inadequately described.

\section{Assessing nutrient distribution}

The levels of average nutrient intake shown in Table 2 agree well with other recent reports on intakes in Britain based on quantitative measurements of food consumption (Nelson et al. 1985). Of course it is possible that the time-consuming task of recording food intake could have resulted in an underestimate of nutrient intake, both in this and numerous other studies. However, it is not clear in what ways such an underestimate would bias the results concerning nutrient distribution.

Family-values are more appropriate than man-values for describing nutrient distribution within families. Man-values are the ratios of intakes of groups of individuals and describe nutrient distribution in the sample as a whole. Family-values, on the other hand, are averages of the ratios of intakes of individuals and take into account the relative ranking of individuals. They describe more accurately than man-values the patterns of consumption within households where 'big' eaters or 'small' eaters tend to be clustered. Both man-values and family-values, however, suffer from sources of bias in their derivation.

The most important of these biases are the mean and the extent of variation of men's intakes. Higher means are associated with lower distribution values and vice versa (Table 4). The means (and distribution values) will be influenced by age, occupation, activity and income, and it may be possible to construct an extensive array of values which take into account the effect of these influences separately or together.

The accuracy of the family-values (more so than the man-values) depends on the accuracy of the measurements of individual intakes. It has been shown (Nelson, 1983) that at each year of age a 1-week record of food consumption was adequate to classify three-quarters of the subjects into the correct extreme thirds of the distribution of intakes of most nutrients (except retinol) and that less than $3 \%$ of individuals were misclassified into the opposite third. This implies that the calculated family-values are reliable, but the exact size of the within-subject variation in family-values could not be calculated with the available information. To do so would have required a second week of recording from the Cambridge families which was not possible in the present study.

Finally, some of the apparent clustering of 'big' or 'small' eaters in the same household shown by family values may be due to method bias, in that households which found the recording difficult may have consistently underestimated all their members' intakes. The extent of this bias could not be quantified.

There were substantial differences between the family-values for energy and other nutrients although relatively few of these differences reached statistical significance (Table 5). It was apparent that most nutrients had a distinct pattern of distribution which reflected differences in the nutrient densities of the diets in the different groups. In general, the values for most nutrients were greater than those for energy, indicating that the average nutrient density of the diets of women and children was greater than that of the men 
Table 6. Average family-values (a) measured and $(b)$ calculated using the recommended daily amounts $(R D A)$ for energy and six nutrients in eight age-sex-groups in seventy-nine Cambridge families

\begin{tabular}{|c|c|c|c|c|c|c|c|c|c|}
\hline \multirow[b]{2}{*}{ Nutrient } & \multirow{2}{*}{$\begin{array}{l}\text { Age-group (years).. } \\
\text { Sex... } \\
n \ldots\end{array}$} & \multicolumn{2}{|c|}{18 and over } & \multicolumn{2}{|c|}{$11-17$} & \multicolumn{2}{|c|}{$5-10$} & \multicolumn{2}{|c|}{ Under 5} \\
\hline & & $\begin{array}{c}3 \\
79\end{array}$ & $\begin{array}{c}\text { ㅇ } \\
79\end{array}$ & $\begin{array}{c}3 \\
27\end{array}$ & $\begin{array}{c}9 \\
26\end{array}$ & $\begin{array}{c}0 \\
34\end{array}$ & $\begin{array}{c}q \\
38\end{array}$ & $\begin{array}{c}0 \\
36\end{array}$ & $\begin{array}{c}q \\
24\end{array}$ \\
\hline \multirow[t]{2}{*}{ Energy } & Measured & $1 \cdot 00$ & $0 \cdot 70^{* * *}$ & $0 \cdot 91^{* *}$ & $0 \cdot 81$ & 0.73 & $0 \cdot 61^{* * *}$ & $0 \cdot 50$ & 0.48 \\
\hline & RDA & $1 \cdot 00$ & 0.83 & $1 \cdot 03$ & 0.82 & $0 \cdot 74$ & 0.72 & $0 \cdot 50$ & 0.51 \\
\hline \multirow[t]{2}{*}{ Protein } & Measured & 1.00 & $0.73 * * *$ & $0 \cdot 84^{* * * *}$ & 0.77 & $0 \cdot 69$ & $0 \cdot 56^{* * *}$ & 0.52 & $0.43^{*}$ \\
\hline & RDA & 1.00 & 0.83 & $1 \cdot 03$ & 0.82 & $0 \cdot 74$ & 0.71 & 0.49 & 0.49 \\
\hline \multirow[t]{2}{*}{ Calcium } & Measured & 1.00 & $0.81^{* * *}$ & $0 \cdot 86^{* * *}$ & $0.82^{* * *}$ & $0.83^{* * *}$ & $0 \cdot 71^{* * *}$ & $0.81^{* * *}$ & $0.64^{* * *}$ \\
\hline & RDA & 1.00 & $1 \cdot 00$ & $1 \cdot 37$ & $1 \cdot 40$ & $1 \cdot 21$ & $1 \cdot 20$ & $1 \cdot 20$ & $1 \cdot 20$ \\
\hline \multirow[t]{2}{*}{ Iron } & Measured & 1.00 & $0.75^{* * *}$ & $0.87^{* * *}$ & $0.77 * * *$ & $0 \cdot 78^{* * *}$ & $0 \cdot 58^{* * *}$ & $0 \cdot 52^{* * *}$ & $0 \cdot 52^{* *}$ \\
\hline & RDA & 1.00 & $1 \cdot 20$ & $1 \cdot 20$ & $1 \cdot 20$ & $1 \cdot 00$ & $1 \cdot 00$ & $0 \cdot 70$ & $0 \cdot 70$ \\
\hline \multirow[t]{2}{*}{ Thiamin } & Measured & $1 \cdot 00$ & $0.77^{* * *}$ & $1 \cdot 07$ & 0.93 & $1 \cdot 03^{* * *}$ & 0.74 & $0.67 * * *$ & 0.57 \\
\hline & RDA & 1.00 & 0.90 & $1 \cdot 08$ & 0.86 & 0.78 & 0.74 & 0.52 & 0.54 \\
\hline \multirow{2}{*}{ Riboflavin } & Measured & $1 \cdot 00$ & 0.80 & 0.95 & 0.81 & $0.93 * * *$ & 0.71 & $0 \cdot 78^{* * *}$ & $0 \cdot 60^{* *}$ \\
\hline & RDA & 1.00 & 0.81 & $0 \cdot 88$ & 0.88 & 0.62 & 0.62 & $0 \cdot 38$ & 0.44 \\
\hline \multirow[t]{2}{*}{ Ascorbic acid } & Measured & 1.00 & 1.09 & $0 \cdot 80$ & 0.88 & 0.80 & 0.62 & 0.74 & 0.72 \\
\hline & RDA & 1.00 & 1.00 & 0.87 & $0 \cdot 83$ & 0.67 & 0.67 & 0.67 & 0.67 \\
\hline
\end{tabular}

Family-value, estimated nutrient intake of each family member $\div$ intake of the male head of the household.

Significance of differences between measured and RDA family-values (two-tailed unpaired $t$ test): ${ }^{*} P<0 \cdot 05$, ** $P<0.01,{ }^{* * *} P<0.001$.

(as can be deduced from Table 2). These findings can often be explained in terms of known eating habits. For instance, the raised family-values for calcium and riboflavin in children aged $0-4$ years reflect their high consumption of milk. High values for thiamin and dietary fibre in boys aged 5-10 years are explained by high consumption of bread and of fibrerich, vitamin-fortified breakfast cereals. The high carotene and ascorbic acid values for women reflect a high fruit and vegetable consumption relative to other family members.

The notably low values for protein and $\mathrm{Fe}$ were due largely to the men's habit of consuming more than their 'fair share' of meat, a major source of both protein and Fe. Men ate $35 \%$ of the total amount of beef and sausages consumed during the survey, but their requirements for protein and Fe (Department of Health and Social Security, 1979) were only $29 \%$ and $22 \%$ respectively, of the total sample requirements.

\section{Assessing dietary adequacy}

Man-values were originally intended to provide the means to assess the adequacy of family diets (Cathcart \& Murray, $1931 \mathrm{~b}$ ). The sum of the values of family members gave the number of 'man-equivalents' in each household. The estimated nutrient content of the household diet was divided by the number of man-equivalents to yield estimates of nutrient intake per ' man'. The adequacy of household diets was assessed by comparing the intake per ' man' with the estimated nutrient requirement of an adult male. This technique was superceded by one in which the sum of the recommended daily allowances of family members is compared with the nutrient contents of the household diet (allowing for meals not eaten at home, waste, etc.). Neither of these techniques addresses a fundamental question in family-diet studies: is the average adequacy of household diets a good measure of the adequacy of the diets of groups of like individuals within those households?

In Fig. 1, the $\%$ RDA $_{\mathrm{g}}$ for energy is within $10 \%$ of $\% \mathrm{RDA}_{\mathrm{h}}$. This variation may be within the limits of error for measuring intake and estimating energy requirements in small groups, 
and may not be of physiological importance. By contrast, the differences in $\% \mathrm{RDA}_{\mathrm{g}}$ for Fe probably do have physiological significance (Monsen et al. 1978), but this was masked by the $\% \mathrm{RDA}_{\mathrm{h}}$. This masking occurred because the observed pattern of nutrient distribution was different from that predicted by the RDA. Both patterns are shown in Table 6 . The RDA 'family-values' for energy, protein, calcium and $\mathrm{Fe}$ were higher than the measured values in most groups. Conversely, the RDA family-values for thiamin, riboflavin and ascorbic acid were mostly lower than the measured values. These differences suggest that for certain nutrients the $\% \mathrm{RDA}_{\mathrm{h}}$ may be a poor measure of dietary adequacy because it cannot reveal important variations in adequacy in the subgroups of the sample.

Apart from energy and $\mathrm{Fe}$, the nutrient intake of all the age-sex-groups reached or exceeded the RDA. Yet the pattern of intake (in terms of the RDA) was similar to that in studies where energy and nutrient intakes have fallen below the RDA (Hitchcock \& Gracey, 1978; Valenzuela et al. 1979; Florencio \& Aligaen, 1980; Ferro-Luzzi et al. 1981): men had the most adequate diets, followed by preschool boys or (in some instances) wives, with girls between the ages of 5 and 17 years generally having the least-adequate diets. It is of interest that such patterns persist regardless of the level of intake.

It is theoretically possible to use family-values to predict the distribution of intake within families and thence the dietary adequacy in different age-sex-subgroups. Factors which would influence distribution such as activity levels, food wastage, consumption of food by visitors and the proportion of food obtained from outside the household food supply would all need to be taken into account. The cost and difficulty of this exercise would be substantial. But it is clear that the limitations of household food surveys (such as the NFS) need to be addressed more directly than at present.

Financial support from the Ministry of Agriculture, Fisheries and Food is gratefully acknowledged, as is the practical assistance provided by Pamela Dyson (fieldwork), Ken Day, Chris Dutton and Paul Winter (computing), Alison Paul and Jean Marr (analysis) and all the families who completed the survey so conscientiously. The views expressed in this paper are those of the author and do not necessarily reflect those of the Ministry of Agriculture, Fisheries and Food.

\section{REFERENCES}

British Medical Association (1933). British Medical Journal 25 November Suppl., 1-16.

Cathcart, E. P. \& Murray, A. M. T. (1931 a). Medical Research Council Special Report Series no. 151. London: H.M. Stationery Office.

Cathcart, E. P. \& Murray, A. M. T. (1931 b). Journal of Nutrition 3, 483-489.

den Hartog, A. P. (1972). Nutrition Newsletter 10, 8-15.

Department of Health and Social Security (1979). Report on Health and Social Subjects no. 15. London: H.M. Stationery Office.

Ferro-Luzzi, A., Norgan, N. G. \& Paci, C. (1981). Nutrition Reports International 24, 153-163.

Florencio, C. A. \& Aligaen, M. B. (1980). Nutrition Reports International 21, 375-385.

Hitchcock, N. E. \& Gracey, M. (1978). Medical Journal of Australia 1, 359-362.

Medical Research Committee (1917). Medical Research Council Special Report Series no. 13. London: H. M. Stationery Office.

Medical Research Council (1924). Medical Research Council Special Report Series no. 87. London: H.M. Stationery Office.

Ministry of Agriculture, Fisheries and Food (1984). Household Food Consumption and Expenditure: 1982. London: H.M. Stationery Office.

Monsen, E. R., Hallberg, L., Layrisse, M., Hegsted, D. M., Cook, J. D., Mertz, W., Finch, C. A. (1978). American Journal of Clinical Nutrition 31, 134-141.

Nelson, M. (1983). A dietary survey method for measuring family food purchases and individual nutrient intakes concurrently, and its use in dietary surveillance. PhD Thesis, University of London.

Nelson, M., Dyson, P. A. \& Paul, A. A. (1985). British Journal of Nutrition 54, 373-387. 
Nelson, M. \& Nettleton, P. A. (1980). Journal of Human Nutrition 34, 325-348.

Office of Population Censuses and Surveys (1971). Classification of Occupations. London: H.M. Stationery Office. Paton, D. N. \& Findley, L. (1926). Medical Research Council Special Report Series no. 101. London: H.M. Stationery Office.

Paul, A. A. \& Southgate, D. A. T. (1978). McCance and Widdowson's The Composition of Foods. London: H.M. Stationery Office.

United States Department of Agriculture (1900). Bulletin no. 84. Washington DC: US Government Printing Office.

Valenzuela, R. E., Florencio, C. A. \& Guthrie, H. A. (1979). Nutrition Reports International 19, 573-581.

Wiles, S. J., Nettleton, P. A., Black, A. E. \& Paul, A. A. (1980). Journal of Human Nutrition 34, 189-223. 